\title{
Morphsyntax Learning through Story Telling using Character Fairy Tales on Early Childhood Education in Banjarmasin
}

\author{
Rusma Noortyani \\ Lambung Mangkurat University \\ Banjarmasin, Indonesia \\ rusmanoortyani@unlam.ac.id
}

\begin{abstract}
This study was based on the results of observations on the early childhood education of children aged four to five years who need to gain experience in the language learning, namely through morphosyntax. This study aimed to assess the morphosyntax learning through the storytelling using character fairy tales in early childhood education (PAUD) in Banjarmasin. The research method used was a descriptive qualitative method. This method was appropriately used since the implementation of morphosyntax learning occurs naturally, as the way it is, and in a normal situation according to the circumstances and conditions of early childhood children in Banjarmasin. The research data were in the form of utterances of words, phrases, clauses, and sentences from 132 children aged 4-5. The learning activities were done through the storytelling of $\mathbf{1 5}$ pieces of character fairy tales. The data were collected from 2015-2016 through participant observation using guided observation guide. The data analysis techniques include 1) data analysis, 2) data presentation, 3) verification, and 4) inference/conclusion. The results showed the data in the form of monomorphemic words, the use of affixes. The phrases found were in the form of a noun phrase, verb phrase, adjective phrase, numerals phrase, prepositional phrase, adverbial phrase, the pronoun phrase, ecocentric phrases, and coordinative phrases. The clauses which were found consisted of noun clause, verb clause and adverb clause. Furthermore, the sentences found were simple sentence and compound sentence
\end{abstract}

Keywords-morphosyntax; fairy tales; children's early childhood

\section{INTRODUCTION}

Morphosyntax learning is part of language learning. Language learning involves linguistic discipline called linguistics. In linguistic studies, there are several branches of science including phonology, morphology, syntax, and semantics. Language learning takes place as we learn to speak, and the majority of languages a child receives start from their mother tongue. Since the time they were born and cried for the first time. This is their way of communicating themselves though nonverbal form. The evidence explains that the child is ready to speak. Along with their physical development, the development of the language of children also takes place.

The role of language with regard to the development of children is closely related to the language use. According to [1], Language learning refers to second language acquisition hypothesis (B2) after a child gets their first language (B1). In language learning, it is believed that a second language can be mastered only by learning through intentional and conscious ways. Language learning deals with the processes that occur when a child learns a second language after they get their first language [2]. The language development of the children always starts from simple words to more complicated and concrete words. Children develop their language potential in a visible way in their first two years of development. Their ability in this period demonstrates its syntactic and morphological abilities more explicitly.

Based on the study of science clusters in Early Childhood Education subsequently abbreviated as PAUD in Indonesian context and its implementation in some countries, Early Childhood Education is started since the age of $0-8$ years [3]. The scope of Early Childhood Education includes the age of 01 categorized as infancy, the age of 2-3 categorized as the age when children start to learn, and the age of 3-6 years categorized as the age when children have started to enter kindergarten school (hence TK in Indonesian term). Thus, children aged 0-6 years who are basically in the golden phase are the targets of Early Childhood Education. The level of Early Childhood Education which conducts formal education of children aged 6 years and below is called kindergarten (TK). The emphasized curriculum is to provide stimuli to assist the growth and development of children in order to have the readiness to enter further education level. In general, it takes 2 years to pass the kindergarten program. With regard to this matter, it can be said that the purpose of the implementation of early childhood education in kindergarten is to improve the creative power of children and encourage them to learn to know various kinds of knowledge through the linguistic approach, religious approach, social and emotional approach, physical approach, motor approach, cognitive approach, art approach independence. This is in line with the view of [4] who states that in principle, the educational needs of kindergarten children must be tailored to the nature of children in which they like to play, like to move, are curious, are honest, like to be friends, like to try new things, want to imitate and want to win.

The study of morphosyntax in Early Childhood Education in Banjarmasin has not been conducted yet to the researcher's knowledge. A similar study which can be found is conducted by [5] entitled Syntax in Children's Utterance in Cinta Ananda Early Childhood Education Banjarmasin. The results of the study indicated parts of the syntax namely phrases, clauses, and basic sentences. Second, [6] conducted a study entitled The Acquisition of Lexicon of Children in Early Childhood Education in Banjarmasin City of South Kalimantan Province. 
The results of the study showed that nouns and verbs were more acquired by the children than the adjectives and task words, especially at the age of 3.0 and 4.0 years. In the acquisition of vocabulary, it was found that more children mastered the Indonesian word when compared with Banjarese language. Third, [6] conducted a study entitled Phonology Aspects of Language Acquisition in PAUD of North Banjarmasin District. The results of the study were (1) minimal consonant and vowel pairs, (2) distribution of vowel, consonant and diphthong phonemes, (3) common vowels and consonant clusters, (4) vowel and consonant allophones, (5) words, (6) the determination of syllable structure, and (7) phonotactic. Fourth, the study by [6] entitled The Acquisition of Vocabulary by Children in Early Childhood Education in Banjarmasin City showed that nouns and verbs appear to have been acquired more by PAUD children than the adjectives, adverbs, pronouns, numerals, prepositions, conjunctions, interjections, articles and particle words, especially at ages 3.0 and 4.0 years.

The four previous studies are different from the current study. The difference lies in the term of language learning which was previously about language acquisition. In addition, there was a research conduct on learning but its scope was in terms of syntax. The present study is concerned with the study of morphosyntax. Previous studies conducted in a foreign setting outside Indonesia were found related to morphosyntax. First, [7] conducted a study entitled Vocabulary Acquisition through Reading, Writing, and Tasks: A Comparison. This study took the subjects of Aoyama Japanese Gakuin University students who were studying English as a foreign language. The study demonstrated that the language proficiency level of learners was significantly influenced by words which were studied with external-driven conditions and the size of the learner vocabulary was significantly influenced by the number of words learned in each condition. Second, [8] study entitled Vocabulary Acquisition from Listening to Stories involved 178 seven-year-old students from 7 classes from 7 schools in New Zealand. The students studied to speak English as the first language. The results of the study showed that all teachers followed the same experimental procedure and read for children in their own classes. The results in the two experiments showed the addition of significant vocabulary. In the first experiment, the teachers read the story of Gumdari op at Sea, while in the second experiment the teachers read the story of Rapscallion Jones. Elley's study did not examine early childhood education children but school children. Elley's study is clearly different from current research because the data collection is done naturally and the data is not collected through experiment but by cross-sectional technique.

Language development of children has been studied by [9] who stated that the pattern of communication of children aged 2-3 years, between the ages of 2-3 years, experience the rapid development of language. Although each child has a different development, at the age of 2 most children can follow simple directions or instructions. The children's development of syntactic will begin to increase when entering the age of two to three years.

One way to enable children to produce a complex acquisition is to ask them to retell the character fairy tales they have heard. The selected tale should match the age of children and interest children to listen. Every child has a natural tendency to listen to a fairy tale or story. In play and study groups, children's enthusiasm when listening to a fairy tale is enormous. Fairytale story-telling activity will provide stimulus so that children can provide a positive response in the form of developed imagination and ability of in retelling what they have heard. Indirectly, these activities strengthen memory, support literacy in children from an early age, expand the creative potential of children, increase vocabulary so that children are more actively talking and children can make more complex sentences. The purpose of storytelling is to pour ideas into children's mind, not only to entertain the listener but also to transmit the values contained in the core of the story. In addition to enriching children's vocabulary, storytelling can regulate the emotions of children [10]. Storytelling provides an excellent forum for children to develop more sophisticated listening and speaking skills. Children's experiences through stories with the beauty and rhythm of the language through literary cultivate an understanding of the various conventions of stories, genres, plots, characters, styles, and motives Cooper, Collins \& Saxby in [11]. Ref. [11] adds that telling stories has an important role in the education of young children and their imagination will be inspired since they create their own visual images and ideas. Their minds will be challenged, and their language skills will be further cultivated as they are inspired by the experience and explore the form of all language skills. Children will also develop closer relationships and a sense of community through the intrinsic social experience of the story.

\section{MEthodS}

This study used the descriptive qualitative method. The descriptive study aims to make the observation of certain phenomena systematic, factual, and accurate about the facts or the characteristics of the population in certain areas [12]. The research method used was qualitative with the approach of language acquisition. This approach was selected since it as considered appropriate to examine the vocabulary acquisition of children in early childhood. In the language acquisition approach, there is a cross-sectional technique that can be used to examine many objects. This is consistent with the views of [13] who suggest that a cross-sectional approach examines a larger number of subjects about their linguistic performance and their performance data should be collected only at one particular session or time. Meanwhile, [14] states that crosssectional studies are consistently accurate when focused on the meaning of communication.

The location of the study was in Early Childhood Educations (PAUD) at Kota Banjarmasin. There are four PAUDs that serve as the location of this study. They are PAUD Nurul Ibadah at Mahat Kasan Street No 61 Gatot Subroto Banjarmasin East, PAUD Nusantara at Belitung Simpang Rahmat Street No. 41A RT 39 West Banjarmasin, PAUD Cinta Ananda on Sungai Mesa Street RT 13 RW 2 Central Banjarmasin and PAUD Aisyiyah Bustanul Athfal 42 at Jalan Perdagangan Street HKSN Permai Complex RT 26 No 1 North Banjarmasin Subdistrict. 


\section{RESULTS AND DISCUSSION}

\section{A. Morphology Learning at the Age of 4-5}

Language learning seeks to improve the mastery of communication, both oral and written communication. According to [15], the development of language in early childhood is to direct children to be able to use and express their thoughts by using words. The development of language is more directed so that children can process words comprehensively, express words in understandable body language, understand every word, interpret and convey intently to others, and argue to convince people through the spoken word. Language in early childhood can develop quickly if children have the ability and are supported by a good environment [16].

The findings of this morphological learning study through storytelling of character fairy tales in children with the age of 4-5 include monomorphemic forms using Indonesian passive prefixes such as [di-]. Although still in a simple stage, this development is very helpful in the development of syntax. The impact on this broad syntactic occurs on the whole structure of the sentence which will change. It can be seen in the use of passive prefix of [di-] in the following examples:

(1) [dibawa rubah licik]

(2) [dimakan seekor serigala]

Children of Early Childhood Education aged 4-5 years old have been aware of the existence of passive verbs indicating that the children have known the existence of two morphemes in a verb. This capability is more visible when they distinguished the prefix [di-] and the prefix [ter-] such as:

(1) [terawat pohon mawar tua]

(2) [dirawat dulu]

Subsequently, prefix [ber-] appears on the following:

(1) [bersandar dan beristirahat]

(2) [berlayar dengan jauh]

Based on the explanation, it can be inferred that language development of children from Early Childhood Education aged 4-5 years is a development of vocabulary, speaking and listening, so that the children aged 4-5 years old are able to express words[17] that can be understood by others. The storytelling of character fairy tales with 15 titles is expected to develop the children's ability to speak fluently using the monomorphemic words and affix. This is supported by the opinion of [17] who asserts that the language development of the children takes place as long as the human mental state is active and the environment to learn is present. At the age of 4 , the development of children's vocabulary reaches 4,000-6,000 words and they can speak in 5-6 word sentences. At the age of 5 years, the vocabulary continues to grow to 5,000 to 8,000 words. Ref. [18] says that the language development of children aged 4 to 5 years is as follows: 1) mentioning as many names of objects, animals, plants that have color, shape, or according to certain characteristics, 2) telling the events in their surrounding in simple form, 3) following one to two orders at once, and 4) making as many words from the initial syllable provided in oral form.

\section{B. Syntactic Learning at the Age 4-5}

Early Childhood Education (PAUD) is a place that is very important in developing language in early childhood. The learning of language development in early childhood requires methods, media and appropriate approach for children. Learning through storytelling of character fairy tales will produce simple sentences with good and correct language.

The findings of this study on syntactic learning through storytelling of character fairy tales in children of early childhood with age 4-5 showed the certain phrases, clauses, and sentences as shown in Fig. 1, Fig. 2 and Fig. 3.

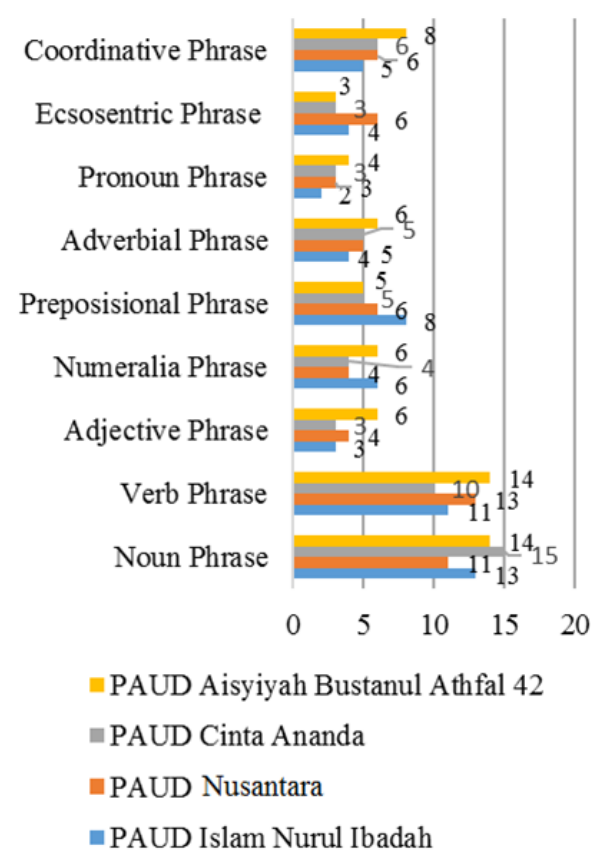

Fig. 1. Types of phrases produced by the children in this study

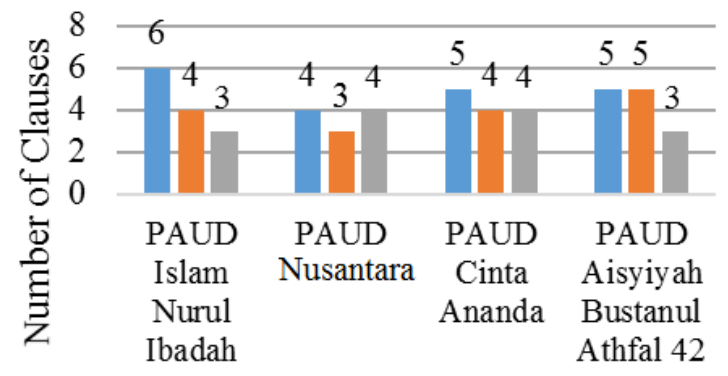

Early Childhood Education

Noun Clause $\square$ Verb Clause $\square$ Adverb Clause

Fig. 2. Types of clauses produced by the children in this study 


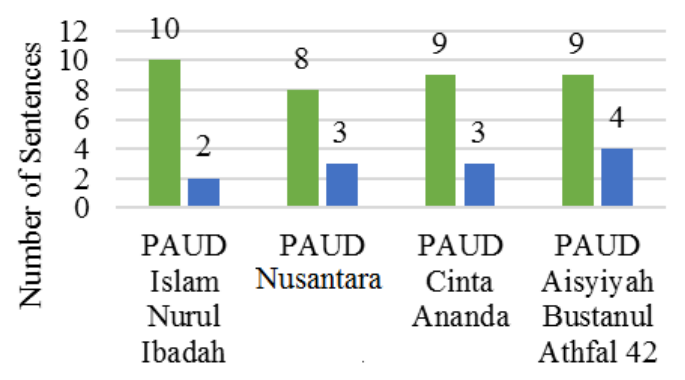

Early Childhood Education

\section{घ Simple Sentence $\quad$ Compound Sentence}

Fig. 3. Types of sentences produced by the children in this study

The data showed that children of the Early Childhood Educations with the age of 4-5 have been able to produce single sentences and compound sentences. This is in line with the opinion of [19] stating that compound sentences are used even more complex. Moreover, [18] asserts that the language development of children aged 4 to 5 is as follows: 1) speaking fluently with simple sentences. 2) telling story. Fairy tales used in this study are shown in Table 1.

TABLE I. THE LIST OF FAIRY TALES USED IN THIS STUDY

\begin{tabular}{|c|c|c|}
\hline No & $\begin{array}{l}\text { Title of Indonesian } \\
\text { character fairy tales }\end{array}$ & Moral Value \\
\hline 1. & $\begin{array}{l}\text { Kesabaran Seorang } \\
\text { Petani }\end{array}$ & $\begin{array}{l}\text { The heart of lazy people is full of } \\
\text { desire, but it is useless, while the heart } \\
\text { of diligent people is full of blessings }\end{array}$ \\
\hline 2. & $\begin{array}{l}\text { Pohon Apel yang Tulus } \\
\text { Hati }\end{array}$ & $\begin{array}{l}\text { The root of the old tree is the best } \\
\text { place to rest. }\end{array}$ \\
\hline 3. & $\begin{array}{lll}\text { Anak Laki-Laki dan } \\
\text { Katak }\end{array}$ & $\begin{array}{l}\text { In this life, always think whether your } \\
\text { happiness can cause others' suffering. }\end{array}$ \\
\hline 4. & $\begin{array}{l}\text { Anak Penggembala dan } \\
\text { Serigala }\end{array}$ & $\begin{array}{l}\text { A liar cannot be trusted although at } \\
\text { one time they tell the truth. }\end{array}$ \\
\hline 5. & $\begin{array}{l}\text { Ayam Jantan yang } \\
\text { Cerdik dan Rubah yang } \\
\text { Licik }\end{array}$ & A cheater is easily frightened. \\
\hline 6. & Angsa Bertelur Emas & $\begin{array}{l}\text { Being too greedy does not give us } \\
\text { anything. }\end{array}$ \\
\hline 7. & $\begin{array}{l}\text { Burung Gagak dan } \\
\text { Seitems Kendi }\end{array}$ & $\begin{array}{l}\text { Although in little amount, knowledge } \\
\text { can help us at the right time. }\end{array}$ \\
\hline 8. & $\begin{array}{l}\text { Burung Pipit dan } \\
\text { Anaknya }\end{array}$ & $\begin{array}{l}\text { Trying by our own effort is the best } \\
\text { help. }\end{array}$ \\
\hline 9. & $\begin{array}{l}\text { Perjuangan Pohon } \\
\text { Bambu }\end{array}$ & $\begin{array}{l}\text { Never regret every day in your life. } \\
\text { Good days will give you happiness, } \\
\text { bad days will give you valuable } \\
\text { experience; both of them are precious. }\end{array}$ \\
\hline 10. & $\begin{array}{l}\text { Angin Utara dan } \\
\text { Matahari }\end{array}$ & Tenderness is better than violence. \\
\hline 11. & Semut dan Belalang & $\begin{array}{l}\text { There is time to work and there is time } \\
\text { to play. }\end{array}$ \\
\hline 12. & $\begin{array}{l}\text { Rubah dan Items } \\
\text { Anggur }\end{array}$ & $\begin{array}{l}\text { Many people pretend to ignore and } \\
\text { underestimate things they cannot } \\
\text { achieve. }\end{array}$ \\
\hline 13. & Pasir dan Batu & $\begin{array}{l}\text { Write your sadness on the soil and } \\
\text { carve your kindness on a stone. }\end{array}$ \\
\hline 14. & $\begin{array}{l}\text { Pemburu dan Penebang } \\
\text { Kayu }\end{array}$ & $\begin{array}{l}\text { Brave people can be seen from their } \\
\text { action. }\end{array}$ \\
\hline
\end{tabular}

\begin{tabular}{|l|l|l|}
\hline 15. & $\begin{array}{l}\text { Petani Jagung yang } \\
\text { Jujur }\end{array}$ & $\begin{array}{l}\text { Do not take what we do not own. If we } \\
\text { keep patient and striving, one day we } \\
\text { will get what we deserve based on our } \\
\text { kindness. }\end{array}$ \\
\hline
\end{tabular}

\section{CONCLUSION}

Learning morphosyntax in children of early childhood aged 4-5 years have shown that morphological learning of the word form is still monomorphemic mostly while the syntactic learning produced by 132 people as a whole is in accordance with the stage of development of their age, the age of 4-5 years. In this study used the standard development of children aged 45 years for children's activities through storytelling characters and in accordance with indicators of child's ability is achieved. For that, we need a plan of play activities with stages such as preparation and implementation of activities.

\section{REFERENCES}

[1] A. Chaer, Pembakuan Bahasa Indonesia, Jakarta:Rineka Cipta, 2002.

[2] A. Chaer, Psikolinguistik: Kajian Teoretik, Jakarta: Rineka Cipta, 2003.

[3] A. Nugraha, and Y. Rachmawati, Metode Pengembangan Sosial Emosional, Jakarta: Universitas Terbuka, 2009.

[4] S. Santoso, Dasar-Dasar Pendidikan TK, Jakarta: Universitas Terbuka, 2009.

[5] S. Ariyani, "Sintaksis dalam Turunan Anak di PAUD CInta Ananda Banjarmasin," Unpublished, 2016.

[6] M. Rafiek and R. Noortyani, Pemerolehan Kosakata Anak Usia Dini di Kota Banjarmasin, Banjarmasin: FKIP Unlam, 2016.

[7] C. Brown, "Vocabulary Acquisition through Reading, Writing, and Tasks: A Comparison," A Dissertation Unpublished, 2003.

[8] W. B. Elley, "Vocabulary Acquisition from Listening to Stories," Reading Research Quarterly, vol. 24, no. 2, pp. 174-187, 1989.

[9] A. Smith, Development of Vocabulary and Grammar in Young America Speaking Children Assessed with a America Language Development Inventory, MI 488® American Speech Language Hearing Association. 2010.

[10] Al-Qudsy, Huhaimin and U. Nurhidayah, Mendidik Anak Lewat Dongeng, Yogyakarta: Madina, 2000.

[11] L. Phillips, "Mendongeng: Benih-Benih Kreatifitas Anak," Australia Journal of Early Childhood, vol. 25, no. 3, pp. 1-5, 2000.

[12] S. Suryabrata, Metodologi Penelitian, Jakarta: Raja Grafindo Persada, 1995.

[13] D. Larsen-Freeman and M. Long, An Introduction to Second Language Acquisition Research, London, and New York: Longman, 1991.

[14] R. Ellis, The Study of Second Language Acquisition, Oxford: Oxford University Press, 1995.

[15] Nurgiyantoro, Penilaian dalam Pelajaran Bahasa dan Sastra. Yogyakarta: BPFE, 1999.

[16] N. A., Wiyani and Barnawi, Format PAUD Konsep, Karakteristik \& Implementasi Pendidikan Anak Usia Dini, Yogyakarta: Ar-Ruzz Media, 2012.

[17] S. Suyanto, Konsep Dasar Pendidikan Anak Usia Dini, Yogyakarta:UNY, 2003.

[18] R. Dewi, Berbagai Masalah Anak Taman Kanak-Kanak, Jakarta: Depdiknas, 2005.

[19] S. Carol, \& A. Wasik. Barbara, Pendidikan Anak Usia Dini, Jakarta: PT. Indeks, 2008. 